\title{
Is There a Role for Spirulina Platensis against Reprotoxicity and Oxidative Stress Induced by Gamma Irradiation in Rats?
}

\author{
Aliaa Ezz El Arab, Osama Ahmed Abbas", Eman Ismail Abdel-Gawad \\ Radioisotopes Department, Egyptian Atomic Energy Authority, Giza, Egypt \\ *Corresponding author: osamaabbasy@yahoo.com
}

Received January 20, 2019; Revised March 26, 2019; Accepted May 01, 2019

\begin{abstract}
Ionizing radiation is one of the environmental factors that may contribute to reproductive dysfunction by a mechanism involving oxidative stress. The present investigation was undertaken to study the possible effect of Spirulina platensis ( $300 \mathrm{mg} / \mathrm{kg}$ body weight) daily for 60 days post whole body gamma irradiation of rats at a dose level of $6 \mathrm{~Gy}$. The samples were collected at two times intervals, two weeks and two months. In serum, the concentrations of nitric oxide (NO), as well as, levels of testosterone, follicular stimulating hormone (FSH) and luteinizing hormone (LH) were evaluated. In tissue, DNA fragmentation was estimated by using comet assay technique, in addition to superoxide dismutase (SOD) and reduced glutathione (GSH). The biochemical results revealed that the fragmentation of DNA increased in irradiated groups at both time intervals (after 2 weeks \& 2 months) as compared to control. The disruption in the hormonal levels of testosterone, FSH and LH was demonstrated in the serum of the irradiated and/or Spirulina rats. On the other hand, the administration of Spirulina after irradiation decreased the elevation of serum NO induced by irradiation and improved the significant reduction of antioxidant enzymes level near to control. Moreover, histopathological observations showed great deleterious changes in the structure of testis tissue as a result of irradiation exposure, while the administration of Spirulina restored the structure of testis cell and no changes appeared. These results suggesting that Spirulina contains bioactive metabolites have detrimental effect on steroidogenesis and beneficial role in improving the antioxidant status.
\end{abstract}

Keywords: ionizing radiation, reproductive hormones, superoxide dismutase, reduced glutathione, DNA fragmentation

Cite This Article: Aliaa Ezz El Arab, Osama Ahmed Abbas, and Eman Ismail Abdel-Gawad, "Is There a Role for Spirulina platensis against Reprotoxicity and Oxidative Stress Induced by Gamma Irradiation in Rats?" Journal of Food and Nutrition Research, vol. 7, no. 5 (2019): 377-385. doi: 10.12691/jfnr-7-5-7.

\section{Introduction}

Spirulina platensis (Arthrospira) is a microscopic and filamentous blue green algae belonging to the class of cyanobacteria from the Oscillateriaceae family. Spirulina was initially classified as a plant because of its richness in plant pigments and its ability to photosynthesize. Later, it was classified as bacteria based on the discovery of its genetics, physiology and biochemical properties [1]. Spirulina (sp.) represents an important staple diet in humans and is utilized as a functional food without any significant side-effects. The basic biochemical compositions of spirulina is a protein, it varies between $60-70 \%$ of dry weight [2]. It is also a rich source of macro- and micronutrients including vitamin supplements especially vitamin $\mathrm{B} 12$, vitamin $\mathrm{E}$ and provitamin $\mathrm{A}$ ( $\beta$-carotenes), oligoelements (zinc, iron, calcium, phosphorous, sodium, potassium and manganese), essential fats (e.g., gammalinolenic and oleic acids) and phycocanin $[1,3]$. This alga lacks cellulose cell walls and therefore it can be easily digested [4]. It has been reported that Spirulina platensis has diverse biological activity and the dietary consumption of it has health benefits in preventing or managing certain inflammatory diseases, allergies, cancer, hypercholesterolemia, hyperglycerolemia, environmental toxicant and drug-induced toxicities, viral infections, cardiovascular diseases, diabetes and other metabolic disease [5,6]. Most of Spirulina's health benefits are associated with its antioxidant pigments. Among these pigments, carotenoids (mixture of carotenes and xanthophylls), chlorophyll and the unique blue pigment phycocyanin [7]. Phycocyanin is a lipoprotein rich in a potent antioxidant substance, tetrapyrrole phycocyanobilin. Spirulina is, therefore, considered a potential therapeutic agent for treating oxidative stress-induced diseases [8].

With the development of nuclear technique, human beings are facing more dangerous effects of using ionizing radiation which represents a genuine, increasing threat to mankind and our environment. Occupational exposure of employees at nuclear facilities, researchers using 
radioisotopes or of workers involved in the cleanup and/or storage of nuclear waste materials, and exposure of patients during the therapeutic irradiation of cancer, would all pose a considerable biological hazard [9]. Ionizing radiation is considered as a powerful inducer of oxidative stress through direct and indirect routes. The indirect pathway is much more important, because when water molecules in the body are irradiated; highly reactive and damaging chemical entities are generated leading to large-scale destruction or damage of various biomolecules [10]. Together, the direct and indirect effects of radiation initiate a series of biochemical and molecular signaling events that may culminate in permanent physiological changes or cell death [11]. Oxidative changes may continue to arise after the initial exposure due to continuous generation of reactive oxygen species (ROS) and reactive nitrogen species $[12,13]$. The oxidative stress may spread from targeted cells to non-targeted bystander cells through intercellular communication mechanisms [14]. Nucleic acids are considered the primary site of radiation injury to the cell, followed by the molecules of the cell membrane and other critical biomolecules of the cell system. In this view, many studies showed that DNA damage by radiation may cause cancer; particularly liver cancer as end stage of acute liver injury $[15,16]$, chromosome aberration, birth defects, suppress the immune system and other serious problems [17].

This study was performed to assess the potential effects of Spirulina platensis intervention in irradiated rats, whether Spirulina can bring in changes in DNA damage, reproductive hormonal levels and antioxidant status and to what extent Spirulina exerts its effect on pathological changes.

\section{Materials and Method}

\subsection{Materials}

Spirulina platensis was provided by the Egyptian Agricultural Research Center who collected it from lakes of Wadi El-Natrun, Egypt. Isolation and purification of Spirulina were performed according to the method described previously [18]. Gamma cell-40, cesium-137 source at a dose rate of $0.84 \mathrm{~Gy} / \mathrm{min}$ belonged to National Center for Radiation Research and Technology (NCRRT), Cairo. All other chemicals were of analytical grade.

\subsection{Experimental Model}

Forty two male albino rats (Sprague Dawley) weighing 160-180 gram were procured from Nuclear Research Center, Inshas. The rats were acclimatized for 7 days before the beginning of the experiment under husbandry conditions with controlled temperature and light cycle. The animals had free access to food pellets and tap water. The local committee approved the design of the experiments, and the protocol complied with the guidelines of Animal Welfare Division of the Ministry of Environment \& Forest, Council of International Organization of Medical Sciences (WHO/UNESCO), NIH and PHS. This guide was approved by the Ethical Committee at National Center for Radiation Research, Egyptian Atomic Energy Authority, Cairo, Egypt (NCRR- EAEA). Rats were randomly divided into seven groups, consisting of six rats in each. Control group: rats received normal food and water throughout the experiment. Spirulina platensis groups: rats administered orally on a daily basis with $S p$. (300 $\mathrm{mg} / \mathrm{kg}$ per day) suspended in distilled water for 60 days. Irradiated groups: rats subjected to a single dose ( $6 \mathrm{~Gy})$ of whole body irradiation. Irradiated- Spirulina platensis groups: rats were administered $S p$. on the next day of irradiation in the same previous manner.

\subsection{Samples Collection}

The samples were collected at two times intervals, two weeks and two months. Rats were subjected to ether anesthesia and blood samples were drawn from the retro-orbital vein. The blood was centrifuged for $10 \mathrm{~min}$ at $5000 \mathrm{rpm}$ and at $4^{\circ} \mathrm{C}$ and then stored for $\mathrm{NO}$ and hormonal analysis. The testis was immediately excised and rinsed in ice-cold saline to remove the excess blood thoroughly and homogenized for assay of DNA fragmentation and oxidative stress parameters (GSH and SOD).

\subsection{DNA Fragmentation (Comet Assay)}

Half gram of crushed samples was transferred to $1 \mathrm{ml}$ ice-cold phosphate buffer saline (PBS). This suspension was stirred for $5 \mathrm{~min}$ and filtered. Cell suspension $(100 \mu \mathrm{l})$ was mixed with $600 \mu \mathrm{l}$ of low-melting agarose $(0.8 \%$ in PBS). $100 \mu \mathrm{l}$ of this mixture was spread on pre-coated slides. The coated slides were immersed in lyses buffer (0.045 M Tris/Borate/EDTA buffer (TBE), pH 8.4, containing 2.5\% Sodium Dodecyl Sulfate (SDS)) for 15 min. The slides were placed in electrophoresis chamber containing the same TBE buffer, but devoid of SDS. The electrophoresis conditions were $2 \mathrm{~V} / \mathrm{cm}$ for $2 \mathrm{~min}$ and $100 \mathrm{~mA}$. Staining with ethidium bromide (EtBr) $20 \mu \mathrm{g} / \mathrm{ml}$ at $4{ }^{\circ} \mathrm{C}$ was performed. The observation continued with the sample during its moisture, the DNA fragment migration patterns of 100 cells for each dose level were evaluated with a fluorescence microscope (With excitation filter 420-490nm [issue 510nm]). The comets tails lengths were measured from the middle of the nucleus to the end of the tail with 40x increase for the count and measure the size of the comet. For visualization of DNA damage, observations are made of Et-Br-stained DNA using a 40x objective on a fluorescent microscope [19].

Although any image analysis system may be suitable for the quantitation of Single cell gel electrophoresis (SCGE) data, we use a comet 5 image analysis software developed by Kinetic Imaging, Ltd. (Liverpool, UK) linked to a charge-coupled device camera (CCD) to assess the quantitative and qualitative extent of DNA damage in the cells by measuring the length of DNA migration and the percentage of migrated DNA. Finally, the program calculates tail moment. Generally, 50 to 100 randomly selected cells are analyzed per sample [19].

\subsection{Biochemical Analysis}

Serum concentrations of testosterone $(\mathrm{T})$ was measured by radioimmunoassay using a commercial kit obtained from DiaSource catalog number KIP1709 whereas luteinizing hormone (LH) was measured by ELISA 
technique using rat LH ELISA kit from KAMIA BIOMEDICAL COMPANY catalog number KT-21064 and follicle stimulating hormone (FSH) by using rat $\mathrm{FSH}$ ELISA kit from BioVendor research and diagnostic products catalog number: RSHAKRFS-010R. Also, nitric oxide value was determined in serum using the method of Nitric oxide (NO) colorimetric assay kit provided from BioVision catalog number: K262-200. The supernatant of testicular homogenates was used for determination of reduced glutathione (GSH) and superoxide dismutase (SOD) levels according to the method [20,21]. Protein was quantified according to Lowry method [22].

\subsection{Histopathology}

Testes of rats were taken from the different groups and fixed in $10 \%$ formalin for $24 \mathrm{~h}$. The samples were washed with tap water, and then serial dilutions of alcohol (methyl, ethyl, and absolute ethyl) were used for dehydration. The specimens were cleared in xylene and embedded in paraffin at $56{ }^{\circ} \mathrm{C}$ in a hot air oven for $24 \mathrm{~h}$. Paraffin - bees wax tissue blocks were prepared for sectioning at $4 \mu \mathrm{m}$ with a sliding microtome. The tissue sections were collected on glass slides, de-paraffinized, and then stained with hematoxylin and eosin [23] and examined using light microscopy.

\section{Results}

\subsection{DNA Damage}

The effects of irradiation on DNA damage in testis of rat have been investigated using comet assay, which allows the detection of DNA alterations of diverse types, such as double-strand breaks, single-strand breaks, alkali-labile sites, incomplete repair sites, and cross-links. An increase in DNA damage was indicated by an increase in migration length of the stained DNA as shown in Table 1. Control testis cells of rat showed no tails (Figure 1.A). Spirulina groups showed neglected changes in DNA after two weeks and two months (Figure 1.B \&C). Increased level of DNA degradation (comet tail length) was evident in irradiated rats after two weeks (Figure 1.D) and after two months (Figure 1.E). After administration of Spirulina, the extent of DNA damage decreased significantly by the time (Figure $1 . F \& G$ ) but did not reach the control level.

\subsection{Biochemical Results}

As depicted in Table 2, rats subjected to Spirulina and/or irradiation showed a massive decrease in the serum hormonal level (testosterone, FSH and LH) at time intervals, 2 weeks and 2 months as compared to corresponding control. This reduction was more pronounced in testosterone level particularly after 2 weeks. As shown in Table 3, oral administration of Spirulina induced a marked improvement in both oxidative stress parameters, GSH and SOD. On the other hand, exposure to irradiation detrimental to the redox status as evidenced by a significant rise $(p<0.05)$ in NO level and significant depletion $(\mathrm{p}<0.05)$ in GSH, SOD activities at both time intervals ( 2 weeks \& 2 months) when compared to controls. As compared to the irradiated groups, supplementation of Spirulina after irradiation dramatically normalized the changes in NO, GSH and SOD content at $2^{\text {nd }}$ week and $2^{\text {nd }}$ month.

Table 1. Score of DNA damage in cells from different groups of male rats

\begin{tabular}{|c|c|c|c|c|c|c|c|}
\hline \multirow{2}{*}{$\begin{array}{l}\text { Groups } \\
\text { fragmentation }\end{array}$} & \multirow{2}{*}{ Control } & \multicolumn{2}{|c|}{ Sspirulina groups } & \multicolumn{2}{|c|}{ Irradiated groups } & \multicolumn{2}{|c|}{ Irradiated-Spirulina groups } \\
\hline & & 2 weeks & 2 months & 2 weeks & 2 months & 2 weeks & 2 months \\
\hline Tailed $\%$ & 1 & 1 & 2 & 15 & 10 & 9 & 7 \\
\hline Untailed \% & 99 & 99 & 98 & 85 & 90 & 91 & 93 \\
\hline Tail length $(\mu \mathrm{m})$ & 1.11 & 1.21 & 1.31 & 3.71 & 3.148 & 2.54 & 2.06 \\
\hline Tail DNA \% & 1.22 & 1.34 & 1.21 & 3.75 & 3.25 & 3.655 & 3.14 \\
\hline Tail moment UNIT & $1.0^{\mathrm{a}} \pm 0.02$ & $1.0^{\mathrm{a}} \pm 0.01$ & $1.38^{\mathrm{a}} \pm 0.01$ & $13.15^{\mathrm{b}} \pm 0.02$ & $10.23^{\mathrm{c}} \pm 0.07$ & $8.68^{\mathrm{b}} \pm 003$ & $6.63^{\mathrm{c}} \pm 0.04$ \\
\hline
\end{tabular}

Values represent means \pm S.E.

Values with the same superscript in the raw are not statistically different.
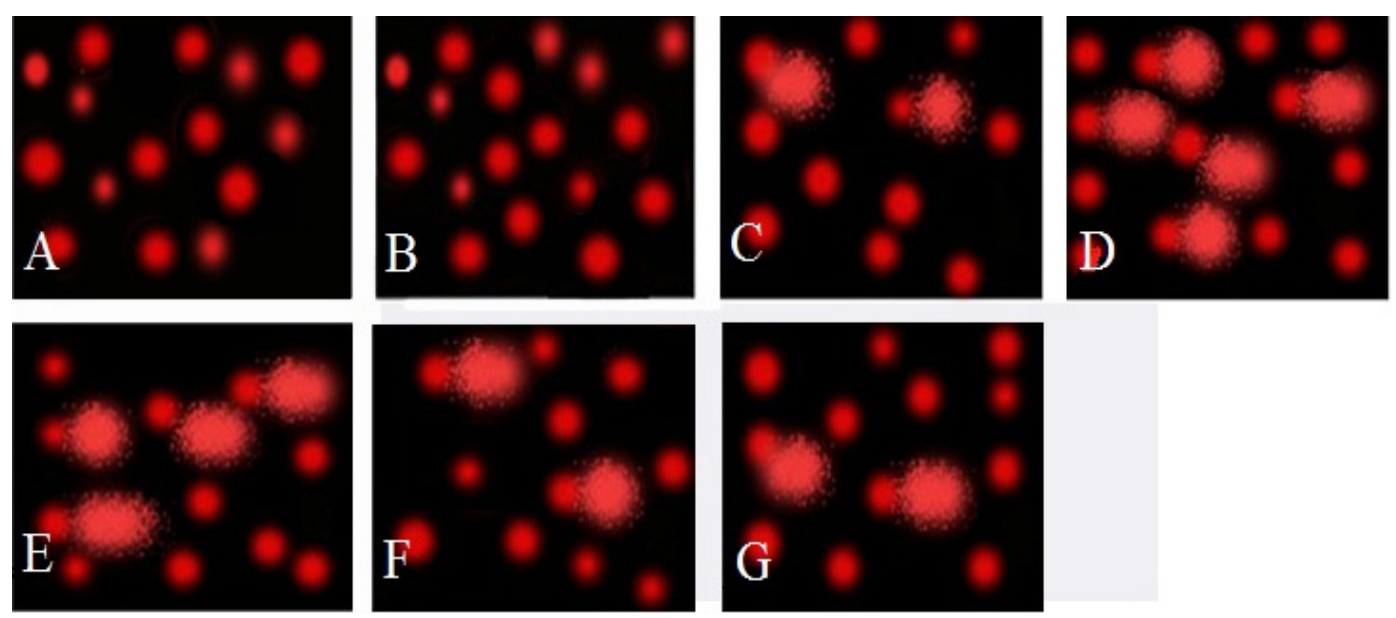

Figure 1. Detection of DNA fragmentation in rat testis by comet assay. (A)Control group. (B) Sp.gp. (2 weeks). (C) $S p$.gp. (2 months). (D) Irrad. gp. (2 weeks). (E) Irrad. gp. (2 months). (F) Irrad-Sp.gp. (2weeks). (G) Irrad.-Sp.gp. (2 months) 
Table 2. Effect of irradiation and/or Spirulina on hormonal level in male rats

\begin{tabular}{|l|c|c|c|}
\hline Proups & Parameters & $\begin{array}{c}\text { FSH } \\
(\mathrm{ng} / \mathrm{ml})\end{array}$ & $\begin{array}{c}\text { LH } \\
(\mathrm{pg} / \mathrm{ml})\end{array}$ \\
\hline Control & $26.95^{\mathrm{a}} \pm 2.11$ & $1403.96^{\mathrm{a}} \pm 3.87$ & $44.87^{\mathrm{a}} \pm 0.66$ \\
\hline Sp. after 2 weeks & $25.67^{\mathrm{a}} \pm 1.76$ & $1387.23^{\mathrm{a}} \pm 5.34$ & $33.34^{\mathrm{a}} \pm 0.58$ \\
\hline Sp. after 2 months & $24.89^{\mathrm{a}} \pm 1.99$ & $1364.78^{\mathrm{a}} \pm 2,67$ & $36.65^{\mathrm{a}} \pm 1.05$ \\
\hline Irrad. after 2 weeks & $17.60^{\mathrm{b}} \pm 0.89$ & $1155.42^{\mathrm{b}} \pm 4.33$ & $32.29^{\mathrm{b}} \pm 1.27$ \\
\hline Irrad. after 2 months & $20.00^{\mathrm{bc}} \pm 1.23$ & $1269.43^{\mathrm{bc}} \pm 6.29$ & $34.89^{\mathrm{b}} \pm 2.01$ \\
\hline Irrad-sp. after weeks & $16.71^{\mathrm{b}} \pm 0.54$ & $1044.92^{\mathrm{b}} \pm 1.56$ & $29.35^{\mathrm{bc}} \pm 0.55$ \\
\hline Irrad-sp. after 2months & $21.49^{\mathrm{bc}} \pm 0.59$ & $1258.45^{\mathrm{bc}} \pm 2.19$ & $35.70^{\mathrm{b}} \pm 0.84$ \\
\hline
\end{tabular}

Values represent means \pm S.E.

Values with same superscript in the raw are not statistically different.

Table 3. Effect of irradiation and/or spirulina on oxidative stress biomarkers (serum NO and testicular GSH and SOD) in rats

\begin{tabular}{|c|c|c|c|}
\hline $\begin{array}{ll}\text { Groups } & \text { Parameters } \\
\end{array}$ & $\begin{array}{c}\mathrm{NO} \\
(\mathrm{nmol} / \mathrm{ml})\end{array}$ & $\begin{array}{c}\mathrm{GSH} \\
(\mathrm{nmol} / \mathrm{mg} \text { protein) }\end{array}$ & $\begin{array}{c}\text { SOD } \\
\text { (U/mg protein) } \\
\end{array}$ \\
\hline Control & $5.11^{\mathrm{a}} \pm 0.02$ & $290.15^{\mathrm{a}} \pm 2.50$ & $6.79^{\mathrm{a}} \pm 0.04$ \\
\hline$S p$. after $2 \mathrm{w}$. & $5.42^{\mathrm{a}} \pm 0.03$ & $310.65^{\mathrm{a}} \pm 4.23$ & $7.11^{\mathrm{a}} \pm 1.01$ \\
\hline$S p$. after 2 mon. & $5.80^{\mathrm{a}} \pm 0.10$ & $322.58^{\mathrm{a}} \pm 2.37$ & $7.67^{\mathrm{a}} \pm 0.85$ \\
\hline Irrad. after $2 \mathrm{w}$. & $9.61^{\mathrm{b}} \pm 0.12$ & $180.92^{b} \pm 3.11$ & $3.77^{\mathrm{b}} \pm 0.02$ \\
\hline Irrad. after 2 mon. & $11.6^{\mathrm{c}} \pm 0.24$ & $192.87^{\mathrm{bc}} \pm 2.78$ & $2.87^{\mathrm{c}} \pm 0.01$ \\
\hline Irrad- $S p$.after $2 \mathrm{w}$. & $8.65^{\mathrm{d}} \pm 0.06$ & $248.27^{\mathrm{d}} \pm 2.49$ & $5.17^{\text {ad }} \pm 0.04$ \\
\hline Irrad- $S p$. after 2 mon. & $6.60^{\mathrm{ad}} \pm 0.03$ & $267.64^{\mathrm{ac}} \pm 3.11$ & $6.0^{\mathrm{ac}} \pm 0.01$ \\
\hline
\end{tabular}

Values represent means $\pm \mathrm{S}$.

Values with same superscript in the raw are not statistically different.
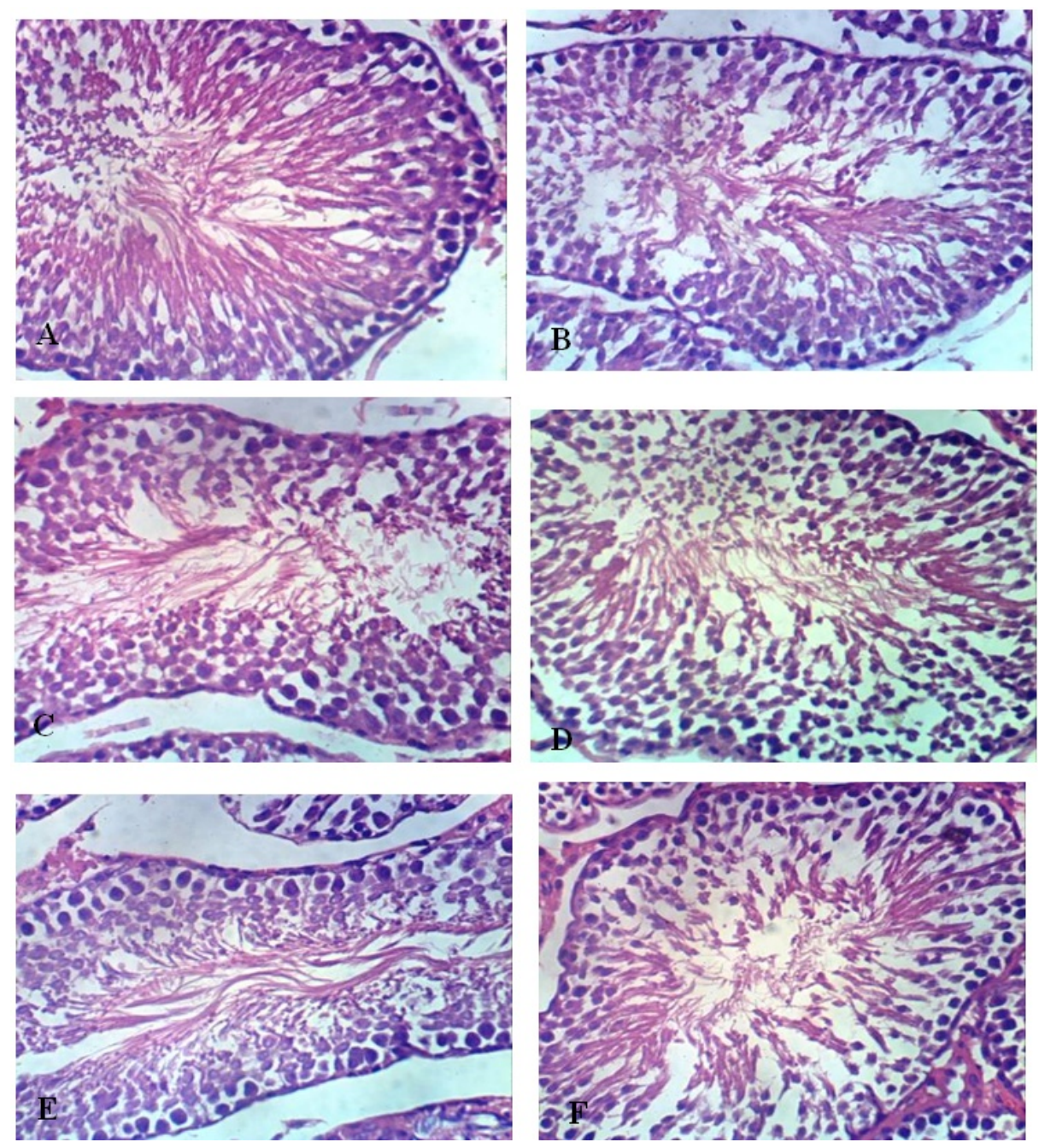

Figure 2. Testis of rats (A\&B) untreated control showing the normal histological structure of seminiferous tubules with normal spermatogoneal cells and complete spermatogenesis, (C\&D) treated with spirulina ( 2 weeks), (E\&F) treated with spirulina (2 months) showing no histopathological changes, $(\mathrm{H} \& \mathrm{E} X \mathrm{400})$ 

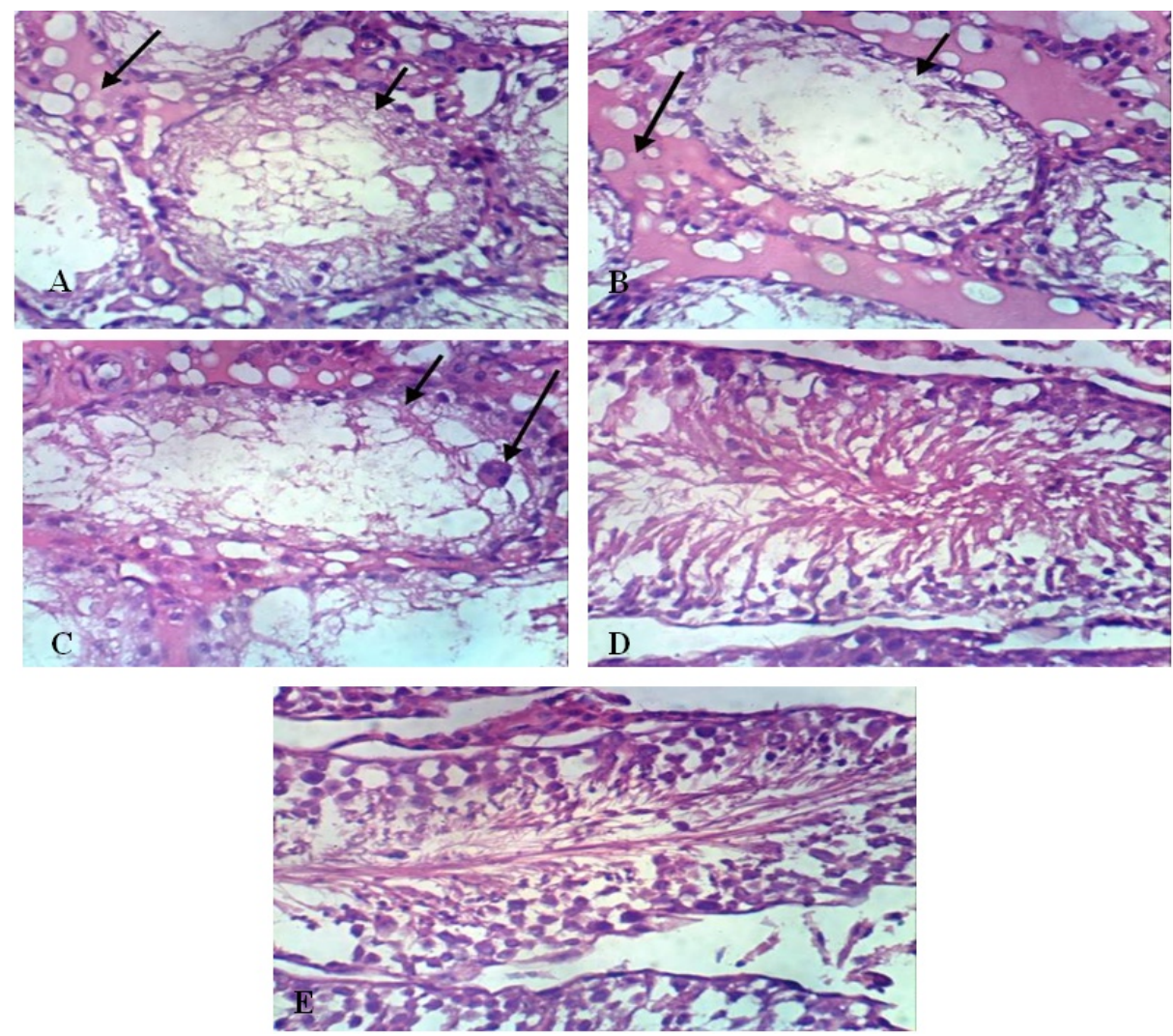

Figure 3. Testis of irradiated rats $(A, B \& C)$ after 2 weeks showing marked degeneration and necrosis of spermatogoneal cells lining seminiferous tubules as well as interstitial oedema, (D\&E) irradiated rats treated with spirulina for 2 weeks showing normal seminiferous tubules with complete spermatogenesis (H \& E X 400)
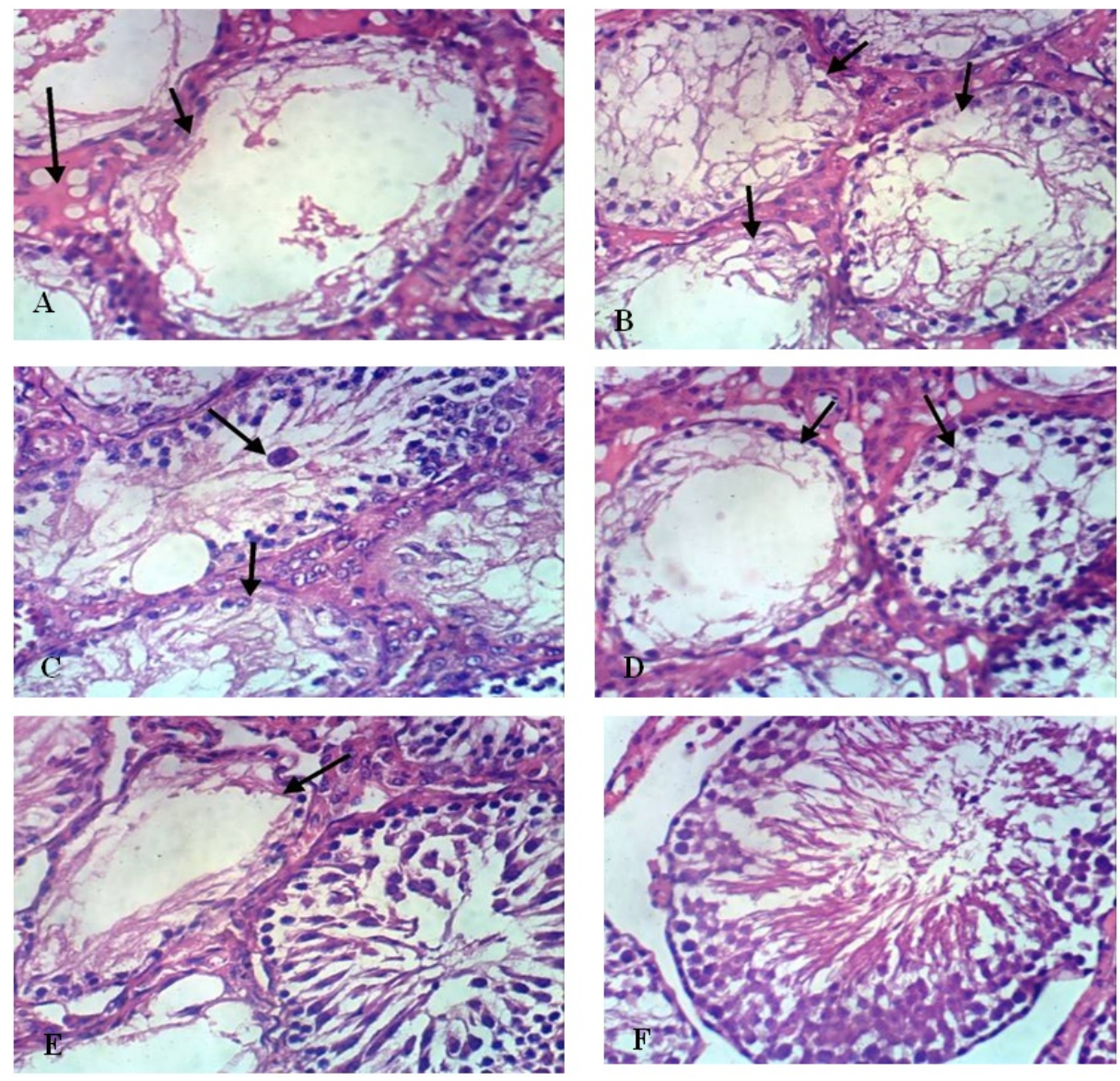

Figure 4. Testis of irradiated rats (A, B \& C) after 2 months showing marked degeneration and necrosis of spermatogoneal cells lining seminiferous tubules as well as interstitial edema, (D \& E) irradiated rat treated with spirulina for 2 months showing degeneration and necrosis of spermatogoneal cells lining some seminiferous tubules, (F) irradiated rat treated with spirulina for 2 months showing no histopathological changes (H \& E X 400) 


\subsection{Histopathology}

Microscopically, testes of control untreated rats revealed the normal histological structure of seminiferous tubules with normal spermatogoneal cells and complete spermatogenesis (Figure 2.A \& B). Rats administered Spirulina only showed no histopathological changes either after 2 weeks (Figure 2.C\&D) or 2 month (Figure 2.E \& F). Testis of irradiated rats showed marked degeneration and necrosis of spermatogoneal cells lining seminiferous tubules as well as interstitial oedema with formation of spermatid giant cells (Figure 3.A, B \& C). Meanwhile, the rat administration $S p$. after irradiation revealed no histopathological changes in testis after two weeks (Figure 3.D \& E). Testis of irradiated rats (Figure 4.A, B \&C) after 2 months showing marked degeneration and necrosis of spermatogoneal cells lining seminiferous tubules as well as interstitial oedema But, some sections of testis of rats administered Spirulina after irradiation for two months showed degeneration and necrosis of spermatogoneal cells lining of some seminiferous tubules (Figure 4.D \& E), whereas other sections from this group revealed normal seminiferous tubules (Figure 4.F).

\section{Discussion}

Radiation damages living cells through two concepts, direct ionization of DNA and other cellular targets and by indirect effect via reactive oxygen species (ROS) and reactive nitrogen species. Exposure to ionizing radiation produces oxygen-derived free radicals in the tissue environment in addition to destructive radicals which are formed through various chemical interactions [24]. Thereby, there is a great attention for protecting patients from the side-effects of radiotherapy, as well as occupational workers in nuclear and radiation plants. Antioxidant supplementation may be an important part of recovery from conventional therapy and perhaps have impact on secondary prevention. Natural compounds are an important source of new antioxidant structures leading to drugs in all major disease areas. They exert their effect through antioxidants content and immune-stimulant activities. At this point, Spirulina seems unique among cellular antioxidants because of its physical and chemical properties; it can easily cross biological membranes and reach the cytosol, nucleus, and cellular compartments [25].

The present data showed that radiation exerts adverse effects on reproductive structures and functions directly at the testicular level. The imbalance between the production and removal of free radicals with sequential impairment of anti-oxidative defense mechanisms is the main reason for radiation hazardous effect. There was a marked increase of oxidatively damaged DNA in irradiated rats as represented by the increase in tail length of DNA migration in the comet assay. Intracellular oxygen determines the extent of DNA damage because oxygen binds to short-lived free radical sites in DNA and fixes the damage. The incident damage to DNA includes DNA breaks, base damage, and destruction of sugars, crosslinks, and telomere dysfunction [26]. On the other hand, the correlation between the increased level of oxidative stress and antioxidant biomarkers in the testis of rats was represented by increase in NO level and decreased levels of GSH along with the antioxidant enzyme SOD. It is well known that nitric oxide is a free radical and it can transform into nitrogen dioxide (this can happen with the hydroperoxy radical, $\mathrm{HO}_{2}{ }^{\circ}$, or diatomic oxygen, $\mathrm{O}_{2}$ ). When ROS production is increased, tetrahydrobiopterin (BH4) generation is reduced and endothelial nitric oxide synthase (eNOS) produce superoxide $\left(\mathrm{O}_{2}{ }^{--}\right)$. Excess generation of $\mathrm{O}_{2}{ }^{-}$by different sources (NADPH oxidase, uncoupled eNOS, xanthine oxidase, myeloperoxidase, cyclooxygenase, mitochondria) will reduce NO bioavailability and convert $\mathrm{NO}$ into peroxynitrite $\left(\mathrm{ONOO}^{-}\right)$, which has deleterious effects [27]. Radiation generates ROS and has a great affinity for $\mathrm{SH}$ groups of biomolecules, thus depleting intracellular thiols including reduced glutathione [28]. It is postulated that the antioxidant GSH depletion by irradiation maybe a trigger for the production of reactive oxygen species (ROS) that induce lipid, protein, and DNA oxidation. Generation of ROS in the cytoplasm of cells may increase the hydrogen peroxide production and lipid peroxidation of mitochondrial membrane, resulting in loss of membrane integrity. Cells have antioxidant defense system including several enzymes functioning in a collective manner for removing free radicals generated within the cells. SOD enzyme is considered the first line of defense against free radical damage. It accomplishes the antioxidant function by detoxifying superoxide anion enzymatically [29]. The decreased activity of SOD might have resulted from the oxidative modification of genes that control this enzyme [30]. Otherwise, GSH is one of the most important compounds, which help in the detoxification and excretion of oxygen radicals. At sufficiently high radiation doses, GSH becomes depleted, leaving highly reactive ROS, beyond the immediate and normal needs of the cell, to react with critical cellular biomolecules and cause tissue damage. It has a role in converting vitamins $\mathrm{C}$ and $\mathrm{E}$ back to their active forms. GSH protects cells against apoptosis by interacting with proapoptotic and antiapoptotic signaling pathways [31]. The concentration of intracellular GSH, therefore, is the key determinant of the extent of radiation-induced testis damage. The sequential development of ROS injury affected also the membrane structure and fluidity leading to disruption of membrane permeability, cellular dysfunction, cellular impairment and finally apoptosis [28]. This phenomenon may be explained by the decrease in the serum level of testosterone in irradiated rats. On the other hand, testosterone synthesis pathways were affected by NO production and/or suppression of luteinizing hormone by intervention of radiation [32]. It is worth to emphasize that radiation reduces the activity of enzymes involved in the biosynthesis of testosterone and decreases the testicular cholesterol, a precursor of testosterone synthesis. It is well known that T, FSH and $\mathrm{LH}$ are the major hormones in male animals and man, which play important roles in male reproduction. In male animals, $\mathrm{T}$ is produced by testis. The secretion of $\mathrm{T}$ is regulated by FSH and $\mathrm{LH}$ which were produced by adenohypophysis. FSH increases Sertoli cell synthesis of an androgen binding protein needed to maintain high concentrations of testosterone. $\mathrm{LH}$ stimulates testosterone production by the interstitial cells 
of the testis [33]. The response of male rats to effects of Spirulina platensis against irradiation-induced oxidative stress and reproductive hormones toxicity was examined in this study. The improved antioxidant status of testicular tissues by Spirulina platensis can be deduced from inhibiting the elevation of $\mathrm{NO}$ and maintaining the endogenous antioxidants enzymes, SOD and GSH in testicular tissues. Such improvement in antioxidant status is indicative of the ROS-scavenging role that Spirulina could play whereby lessening tissue damage and relieving the pathological changes induced by irradiation in testis [34]. It could also be proposed that the beneficial effects of Spirulina may be due to its antioxidant properties that could revive endogenous cellular antioxidant defense system [35]. Thus, interest has been focused on Spirulina as an antioxidant due to the presence of potent antioxidant components and several active ingredients, notably blue polypeptide pigment phycocyanin, as $\beta$-carotene, vitamin $\mathrm{C}$, vitamin $\mathrm{E}, \propto$-lipoic acid and manganese [36,37]. C-phycocyanin is one of the major biliproteins of Spirulina with antioxidant and radical scavenging properties. It has been reported that phycocyanin content of Spirulina has the ability to scavenge free radicals, including alkoxyl, hydroxyl and peroxyl radicals [8]. It also decreases nitrite production and suppresses inducible nitric oxide synthase (iNOS) expression [38]. Another ingredient of Spirulina, $\beta$-carotene, has been reported to have antioxidant activities against singlet oxygenmediated lipid peroxidation and may reduce cell damage, especially the damage to DNA molecules [37]. It also inhibited the production of nitric oxide and prostaglandin, and suppressed the expression of iNOS [39]. In this context, Vitamin E prevents ROS-mediated membrane damage by binding up ROS within the cell membrane and maintains GSH and ascorbic acid levels in damaged tissue [40]. Moreover, vitamin C is well known antioxidant that is present in the testes and involved in the protection function from oxidative damage and improves its vascular function and structure. Researchers have shown that vitamin $\mathrm{C}$ modulated the enzyme systems that generate free radicals by decreasing covalent bonds of reactive intermediates and eliminating free radical metabolites [31]. Scientifically, the synergistic action exhibited by a broad spectrum of antioxidants is more efficient than the activity of a single antioxidant. In addition, antioxidants from natural sources have a higher biocompatibility and, therefore, higher protective efficacy than the synthetic ones.Although Spirulina possessed various positive nutritional and therapeutic properties, few studies reported its side effects. The current study clarified a sharp disturbance observed in the level of the reproductive hormones (testosterone, FSH and LH) of male rats after Spirulina administration. The fluctuation in the hormonal concentration was attributed to the presence of certain bioactive compounds in Spirulina that might have a dysregulative effect on the reproductive hormones [41].

Previous researches $[42,43,44]$ emphasized that the injection of cyanobacterial species induced negative consequences on reproductive system including disruption in the serum level of sex hormones and testis damage. Other proposal which may explain the hormonal issue is the presence of sterol-like compounds in Spirulina [45,46] that might be responsible for the disruption of sex hormones via interfering with the hormone-dependent signaling pathways. Sterol-like compounds can block the metabolism of natural steroid hormones by antagonizing nuclear hormone receptors [47]. Moreover, these compounds may cause perturbations in the level of gonadotropin-releasing hormone which in turn affect the synthesis and the release of FSH and LH [48].

Histopathological observations came to agree with the biochemical results to a great extent. There was no pathological changes in testis sections in rats administered Spirulina after irradiation for two weeks. But, some sections of rats subjected to Spirulina for two months post-irradiation clarified degeneration and necrosis of spermatogoneal cells lining some seminiferous tubules. Such finding confirmed the hypothesis that continuous generation of ROS after initial exposure to irradiation is associated with subsequent elaborate array of damage depending on exposure dose, time after irradiation and affected organ. The testis afford of antioxidant enzymes is less than the stress caused by irradiation.

\section{Conclusion}

Spirulina has dual effects, because it contains antioxidative compounds and sterol-like compounds which may have synergistic effect with irradiation on steroidogenesis.

\section{Conflict of Interests}

The author declares that there is no conflict of interests.

\section{List of Abbreviation}

Spirulina

Reactive oxygen species

National Center for Radiation Research and Technology

National Center for Radiation Research

Egyptian Atomic Energy Authority,

Phosphate buffer saline

Tris/Borate/EDTA buffer

Sodium Dodecyl Sulfate

Ethidium bromide

Single cell gel electrophoresis

charge-coupled device

Testosterone

Luteinizing hormone

Follicle stimulating hormone

Superoxide dismutase

Reduced glutathione

Nitric oxide

peroxynitrite

tetrahydrobiopterin

Nitric oxide synthase

Endothelial nitric oxide synthase

Inducible nitric oxide synthase

Sulfhydryl

Nocotinamide adenine dinucleotide phosphate
$S p$

ROS

NCRRT

NCRR

EAEA

PBS

TBE

SDS

$\mathrm{EtBr}$

SCGE

CCD

$\mathrm{T}$

LH

FSH

SOD

GSH

NO

ONOO

$\mathrm{BH} 4$

NOS

eNOS

iNOS

$\mathrm{SH}$ 


\section{References}

[1] Machu, L., Misurcova, L., Ambrozova, J.V., Orsavova J., Mlcek, J., Sochor, J. and Jurikova, T, "Phenolic content and antioxidant capacity in algal food products", Molecules, 20.1118-1133. 2015.

[2] Hassan, A.M.H, "Application study for producing eco-friendly diet for fish from the blue green algae Spirulina platensis”, $\mathrm{PhD}$, Ain Shams University, Cairo, Egypt. 2016.

[3] Bashandy, S.A.E., El Awdan, S.A., Ebaid, H. and Alhazza, I.M, "Antioxidant Potential of Spirulina platensis Mitigates Oxidative Stress and Reprotoxicity Induced by Sodium Arsenite in Male Rats", Oxid Med Cell Longev, (2016). 1-8. 2016.

[4] Dillon, J.C., Phuc, A.P. and Dubacq, J.P, "Nutritional value of the alga Spirulina", World Rev Nutr Diet, 77. 32-46. 1995.

[5] El-Desoky, G.E., Bashandy, S.A., Alhazza, I.M., Al-Othman, Z.A., Aboul-Soud, M.A. and Yusuf, K, "Improvement of Mercuric Chloride-Induced Testis Injuries and Sperm Quality Deteriorations by Spirulina platensis in Rats", PLoS ONE, 8. e59177. 2013.

[6] Ibrahim, A.E. and Abdel-Daim, M.M, "Modulating Effects of Spirulina platensis against Tilmicosin-Induced Cardiotoxicity in Mice", Cell J, 17.137-144. 2015.

[7] Strömberg, I., Gemma, C., Vila, J. and Bickford, P.C, "Blueberryand spirulina-enriched diets enhance striatal dopamine recovery and induce a rapid, transient microglia activation after injury of the rat nigrostriatal dopamine system", Exp Neurol, 196. 298-307. 2005.

[8] Bhat, V.B. and Madyastha, K.M, "Scavenging of peroxynitrite by phycocyanin and phycocyanobilin from Spirulina platensis: protection against oxidative damage to DNA", Biochem Bioph Res Co, 285. 262-266. 2001.

[9] Abdel-Daim, M., El-Bialy, B., Rahman, H.G., Radi, A.M., Hefny, H.A. and Hassan, A.M, "Antagonistic effects of Spirulina platensis against sub-acute deltamethrin toxicity in mice: Biochemical and histopathological studies", Biomed Pharmacother, 77.79-85. 2016

[10] Hall, E.J. and Giaccia, A.J, "In: Radiobiology for the Radiologist. 6th ed, Physics and chemistry of radiation absorption”, Lippincott Williams \& Wilkins; Philadelphia, PA, USA, 2006. 9.

[11] Lehnert, S, “Biomolecular Action of Ionizing Radiation, Series in medical physics and biomedical engineering”, Taylor and Francis Group, LLC, N.Y USA. 2007. 279.

[12] Fatih Fidan A, Enginar H, Cigerci H, Korcan E, Ozdemir A. The radioprotective potential of Spinacia oleraceae and Aesculuc hippocastanum against ionizing radiation with their antioxidative and antioxidative properties. J Anim Vet Adv 2008; 7: 1528-1536.

[13] Makhlouf, R. and Makhlouf, I, "Evaluation of the effect of Spirulina against Gamma irradiation induced oxidative stress and tissue injury in rats”, Int J Appl Sci Eng Res, 1. 152-164. 2012.

[14] Hei, T.K., Zhou, H., Chai, Y., Ponnaiya, B. and Ivanov, V.N, "Radiation induced non targeted response: mechanism and potential clinical implication", Curr Mol Pharmacol, 4. 96-105. 2011.

[15] Sanchez-Parez, Y., Carrasco-Legleu, C., Garcia-Cuella, C., ParezCarreon, J., Hernandez-Garcia, S., Salcido-Neyoy, M., AlemanLazarini, L. and Villa-Trevino, S, "Oxidative stress in carcinogenesis. Correlation between lipid peroxidation and induction of preneoplastic lesion in rat hepatocarcinogenesis", Cancer Lett, 217. 25-32. 2005.

[16] Sandeep, D. and Nair, C.K, "Protection from lethal and sub-lethal whole body exposures of mice to $\gamma$-radiation by Acorus calamus L.: Studies on tissue antioxidant status and cellular DNA damage" Exp Toxicol Pathol, 64.57-64. 2012.

[17] Jagetia, G.C., Rajanikan, G.K., Shaival. K., Rao, M. and Baliga, S, "Alteration the glutathione, glutathione peroxidase, superoxide dismutase and lipid peroxidation by ascorbic acid in the skin of mice exposed to fractionated $\gamma$ - radiation", Clinica Chimica Acta, 332.111-121. 2003.

[18] Zhang, K., Lu, J., Guo, Y., Sun, B., Zhao, F., Cao, Y. and Ren, D, Effects of different drying processes on the quality of Spiruluna platensis, International agricultural Engineering Journal, 22. 63-71. 2013.

[19] Singh, N.P., McCoy, M.T., Tice, R.R. and Schneider, E.L, “A simple technique for quantitation of low levels of DNA damage in individual cells", Exp. Cell Res, 175.184-191. 1988.

[20] Aebi, H, "Catalase in Vitro", Meth Enzymol, 105.121-126. 1984.
[21] Janknegt, P.J., Rijstenbil, J.W., van de Pol, W.H., Geches, T.S. and Buma, A.G, "A comparison of quantitative and qualitative superoxide dismutase assays for application to low temperature microalgae", J Photochem Photobiol B, 87. 218-226. 2007.

[22] Lowry, O.H, "Rosenbrough NJ, Farr AL, \& Randall RJ, Protein measurement with folin phenol reagent", Biol Chem, 193. 265-275. 1951.

[23] Banchroft, J.D, "Stevens A. foreword by Turner DR, Theory and practice of histological techniques", (6th ed. New York, Churchil Livingstone, USA), 121. 2008.

[24] O'Neill, P. and Wardman, P, "Radiation chemistry comes before radiation biology", Int J Radiat Biol, 85.9-25. 2009.

[25] Matsuo, T., Kashiwaki, Y. and Itoo, S, "Membrane damage caused by exposure to t-butyl hydroperoxide", Phytochemistry, 28.1003-1006. 1989.

[26] Boeck, M.De., Touil, N., Visscher, G.De, Vande, P.A. and Kirsch-Volders, M, "Validation and implementation of an internal standard in comet assay analysis", Mutat Res, 469. 181-197. 2000.

[27] Abdel-Gawad, E.I. and Awwad, S.A, "Biocompatibility of Intravenous Nano Hydroxyapatite in Male Rats", Nat Sci, 8.60-68. 2010.

[28] Ding, G.R. and Guo, G.Z, "Advances in research of radioprotectant", J Radiat Res Radiat Process, 25.321-324. 2007.

[29] Yang, J., Wu, G., Feng, Y., Lv, Q., Lin, S. and Hu, J, "Effects of taurine on male reproduction in rats of different ages", $J$ Biomed Sci, 17(1)/S9.1-8. 2010.

[30] Nur-Hidayah, H., Nurul-Hidayah, K., Rasyidah, Ti., Kaswandi, Ma. and Noah, Rm, "Antioxidant Activities Of Allium Sativum Towards Formalin-Induced Oxidative Stress", In Rat Liver. Regen Res, 3.71-77. 2014

[31] Ismail, M., Hossain, M.F., Tanu, A.R. and Shekhar, H.U, "Effect of Spirulina Intervention on Oxidative Stress, Antioxidant Status, and Lipid Profile in Chronic Obstructive Pulmonary Disease Patients", Biomed Res Int, (2015) Article ID 486120. 2015.

[32] Hong, C.Y., Park, J.H., Ahn, R.S., Im, S.Y., Choi, H., Soh, J., Mellon, S.H. and Lee, K, "Molecular Mechanism of Suppression of Testicular Steroidogenesis by Proinflammatory Cytokine Tumor Necrosis Factor Alpha", Mol Cell Biol, 24.2593-2604. 2004.

[33] Osman, N.N, “Antioxidant Effects of Ferula Hermonis and Bee Honey on $\gamma$-Radiation-Induced Oxidative Testicular Damage in Rats", J Rad Res Appl.Sci, 4.1201-1219. 2011.

[34] Ku, C.S., Pham, T.X., Park, Y., Kim, B., Shin, M., Kang, I. and Lee, J, "Edible blue-green algae reduce the production of proinflammatory cytokines by inhibiting NF- $\mathrm{B}$ pathway in macrophages and splenocytes", Biochim Biophys Acta, 1830.29812988. 2013

[35] Hoseini, S.M., Khosravi-Darani, K. and Mozafari, M.R, "Nutritional and medical applications of Spirulina microalgae", Mini Rev Med Chem, 13.1231-1237. 2013.

[36] Tang, G. and Suter, P.M, "Vitamin A, nutrition, and health values of Algae: Spirulina, Chlorella, and Dunaliella", J Pharm Nutr Sci, 1.111-118. 2011.

[37] Mueller, L. and Boehm, V, “Antioxidant activity of $\beta$-carotene compounds in different in vitro assays", Molecules, 16.1055-1069. 2011.

[38] Balaji, H, "Spirulina-small but a spectacular species", Int J Drug Dev \& Res, 5.76-82. 2013.

[39] Deng, R. and Chow, T.J, "Hypolipidemic, antioxidant, and antiinflammatory activities of microalgae Spirulina", Cardiovasc Ther, 28. e33-e47. 2010.

[40] Garg, M.C., Chaudhary, D.P. and Bansal, D.D, "Effect of vitamin E supplementation on diabetes induced oxidative stress in experimental diabetes in rats", Indian J Exp Biol, 43. 177-180. 2005.

[41] Fathy, S.M. and Essa, A.M, "Influence of Spirulina platensis exudates on the endocrine and nervous systems of a mammalian model", Asian Pac J Trop Biomed, 5.451-457. 2015.

[42] Ding, X.S., Li, X.Y., Duan, H.Y., Chung, I.K. and Lee, J.A, "Toxic effects of Microcystis cell extracts on the reproductive system of male mice”, Toxicon, 48.973-979. 2006.

[43] Damkova, V., Sedlackov, J., Bandouchova, H., Peckova, L., Vitula, F., Hilscherova, K., Paskova, V., Kohoutek, J., Pohanka, M. and Pikula, J, "Effects of cyanobacterial biomass on avian reproduction: a Japanese quail model", Neuroendocrinol Lett, 30.205-210. 2009. 
[44] Essa, A.M. and Fathy, S.M, "Sex hormonal disruption by cyanobacterial bioactive compounds" J Appl Microbiol, 116. 700-709. 2014

[45] Noaman, N.H., Fattah, A., Khaleafa, M. and Zaky, S.H, "Factors affecting antimicrobial activity of Synechococcus leopoliensis", Microbiol Res, 159.395-402. 2004.

[46] Ramadan, M.F., Asker, M.M.S. and Ibrahim, Z.K, "Functional bioactive compounds and biological activities of Spirulina platensis lipids", Czech J Food Sci, 26.211-222. 2008.

[47] Tabb, M.M. and Blumberg, B, "New modes of action for endocrine- disrupting chemicals", Mol Endocrinol, 20. 475-482. 2006.

[48] De Coster, S. and van Larebeke, N, "Endocrine disrupting chemicals: associated disorders and mechanisms of action", J Environ Public Health, (2012)52. 2012.

(C) The Author(s) 2019. This article is an open access article distributed under the terms and conditions of the Creative Commons Attribution (CC BY) license (http://creativecommons.org/licenses/by/4.0/). 